\title{
Teoza (pobožavanje) kao biblijska i povijesna doktrina
}

\author{
Goran Medved \\ Beatus, Zagreb \\ goranmedved@bizg.hr
}

UDK: 27-1:27-23

Izvorni znanstveni članak

https://doi.org/10.32862/k1.13.1.1

\section{Sažetak}

Ovo je prvi od dva članka od ovoga autora, koji istražuju doktrinu teoze, ponekad također zvanu pobožavanje, deifikacija ili divinizacija. Drugi članak predstavlja teozu kao novozavjetnu i evanđeosku doktrinu. Prvi članak predstavlja teozu kao biblijsku i povijesnu doktrinu. Prvi dio ovog članka analizira glavne biblijske tekstove za doktrinu teoze; njihovo tumačenje $i$ usvajanje za teozu. Drugi dio ovog članka pruža pregled povijesnog razvoja doktrine teoze, od početka kršćanske misli do modernog doba. Pokazuje da teoza nije bila ograničena na istočne teologe nego je također bila zastupljena na Zapadu kod određenih vodećih teologa i pokreta. Zbog njezine bibličnosti i povijesnosti, teozu treba smatrati ključnom povijesnom doktrinom Crkve.

Ključne riječi: teoza, pobožavanje, deifikacija, divinizacija, imago dei, sli$k a$, sličnost, obnova, patristička teoza, srednjovjekovna teoza, protestantska teoza

\section{Uvod}

Pažljivi čitatelj Biblije, osobito Novoga zavjeta, mogao bi zaključiti da kršćani više nisu samo ljudska bića. Na primjer, nakon smrti i uskrsnuća Isusa Krista, o kršćanima se govori kao o novom stvorenju. ${ }^{1}$ Nakon izlića Svetog Duha na Pedesetnicu, o kršćanima se govori kao nanovorođenima i ispunjenima Božjim Svetim

1 Na primjer, vidi 2 Kor 5,17; Ef 2,10. 
Duhom. ${ }^{2}$ Drugi novozavjetni tekstovi govore o kršćanima koji su u Kristu ${ }^{3}$ i koji su transformirani u Krista, koji je smatran Bogom. ${ }^{4}$

Biblijski tekstovi poput ovih doprinose kršćanskom konceptu teoze - doktrini koja istražuje na koji se način ljudi pobožavaju. Riječ teoza ne nalazi se u Bibliji. Prvi put su je upotrijebili neki ranokršćanski teolozi koji su razvili koncept i doktrinu teoze. Riječ „teoza“ dolazi od grčke riječi theosis, od korijena theos, što znači „bog“. Tako da teoza doslovno znači „pobožavanje“ ili „postajati poput boga“. Neki teolozi umjesto riječi „teoza“ ili „pobožavanje“ koriste riječi „deifikacija“ ili „divinizacija“. Značenje je riječi jednostavno, ali objašnjenje teoze je složeno.

Crkveni su oci koristili dosta različitih riječi da bi objasnili koncept teoze: „To je transformacija, sjedinjenje, sudjelovanje, dijeljenje, miješanje, uzdizanje, prožimanje, preobrazba, spajanje, izjednačavanje, reintegracija, usvajanje, ponovno stvaranje. Divinizacija podrazumijeva naše ispreplitanje s Kristom, upliv božanskoga, ili postizanje sličnosti s Bogom“ (Clendenin 1994, 374). Teoza se događa kroz naše sjedinjenje s Bogom. Crkveni su oci upotrijebili nekoliko ilustracija iz svakodnevnog života da bi pojasnili teozu. Na primjer, naše sjedinjenje s Bogom može se gledati kao brak između muškarca i žene, gdje dvoje ljudi postaje jedno, ali također ostaju zasebnih identiteta. Ili se može usporediti sa zrnjem žita koje čini kruh, gdje je zrnje sjedinjeno na takav način da se više ne može razlikovati; ili $s$ kvascem u grudi tijesta, koji prožima svaki njegov dio. Ako promatramo kovača koji kuje željezo, možemo vidjeti užareno željezo u vatri, gdje postoji i sjedinjenje i odvojenje tih dvaju stvari, dok se željezo preoblikuje (Clendenin 1994, 374-375).

Osim pojedinih riječi i ilustracija, objašnjavanju teoze doprinose teološke definicije. ${ }^{5}$ Westminster Theological Dictionary pruža definicije za sljedeća tri termina: deifikacija, divinizacija i teoza. Za deifikaciju piše: „Slika spasenja kod ranih istočnih crkvenih teologa u kojoj kroz Krista vjernici mogu postati poput Boga“ (McKim 1996, 73). Za divinizaciju stoji: „Gledište istočnih teologa koje vidi spasenje kao proboj božanskih energija u ljudsko stanje (2 Pt 1,4), započinjući proces sjedinjenja ljudskoga i božanskoga koji se završava uskrsnućem mrtvih“ (McKim 1996, 80). A za teozu navodi: „Gledište koje drže teolozi istočnog pravoslavlja, da se spasenje od grijeha sastoji od procesa 'deifikacije', kojim vjernici postaju sjedinjeni s Kristovom božanskom naravi pa tako i s Bogom“ (McKim 1996, 282).

2 Na primjer, vidi Djela 2,4; 2,33; 4,31; 1 Pt 1,3.23; Ef 5,18.

3 Na primjer, vidi Gal 3,26. Izraz "u Kristu" javlja se više od 100 puta u Novom zavjetu.

4 Na primjer, vidi Rim 8,28; 2 Kor 3,18. Ovo ću podrobnije istražiti u sljedećem članku o teozi pod „Teoza u novozavjetnoj teologiji”.

5 Mnogi teološki rječnici ne sadrže pojam teoze, što govori o rijetkosti tog termina i slabom poznavanju ove doktrine u protestantskom i evanđeoskom kršćanstvu. 
Ovo će proučavanje pokazati da teoza nije ograničena samo na istočne teologe. Prema Russellu, koncept pobožavanja bio je izražen metaforički od početka kršćanske misli, a prva zapisana definicija pojavila se u 6. stoljeću kod Dionizija Areopagita: „Teoza $(\theta \dot{\varepsilon} \omega \sigma ı \varsigma)$ je postizanje sličnosti Bogu i sjedinjenje s njim koliko god je to moguće" (Russell 2004, 1).

Teozu je teško ukratko definirati jer obuhvaća nekoliko elemenata. Suvremeni mislioci pružaju pomalo različite definicije ove doktrine. Rakestraw izjavljuje da je pobožavanje "obnova i reintegracija 'slike' ili, kako neki preferiraju, 'sličnosti' Bogu, koja je ozbiljno narušena padom, u djeci Božjoj” (Rakestraw 1997, 261). Litwa tvrdi: "teoza je sudjelovanje u božanskom identitetu (određenog) Boga. Taj određeni Bog za Pavla je onaj kojega su on i njegove zajednice štovale kao 'Gospodina Isusa Krista”' (Litwa 2012, 32). Strobel definira pobožavanje kao „sudjelovanje po Kristu u Božjem trojstvenom životu, što uzrokuje da ljudska narav poprimi atribute božanske naravi“" (Strobel 2012, 262, 272). Prema Olsonu, "mi postajemo sudionici u Božjoj vlastitoj naravi po energičnoj prisutnosti Krista i Duha u nama, koja nas preobražava u Božje kopije, koje zaista nose nešto od njegova vlastita bića“ (Olson 2007, 199). Collins predlaže: „Teoza je izraz božanskih svrha u stvaranju i otkupljenju: izraz poziva na preobraženje ili preoblikovanje tako da Bog može biti sve u svemu" (Collins 2012, 194). Gormanova jednostavna definicija pobožavanja je „postajati poput Boga sudjelovanjem u Božjem životu" (Gorman 2011, 17), dok njegova potpuno razvijena definicija, na temelju Pavlovih spisa, kaže: “Teoza je preobražavajuće sudjelovanje u kenotičkom [samo-ispražnjavajućem], križolikom [samo-požrtvovnom] Božjem karakteru kroz Duhom omogućeno usklađivanje s utjelovljenim, raspetim i uskrslim/proslavljenim Kristom“ (Gorman 2009, Kindle lokacija 88).

Premda su kratke definicije korisne, one nisu dovoljne. Da bismo u potpunosti razumjeli pobožavanje, moramo pojam razmatrati biblijski i povijesno. Pobožavanje ne znači „postati Bogom“ jer je to nemoguće, a i heretički prema kršćanskoj tradiciji. No ono svakako uključuje preobrazbu, tj. postajanje poput Boga u njegovoj naravi i karakteru. S doktrinom teoze ne iskoračujemo izvan granica Biblije, nego iznosimo biblijsku teologiju.

Ovo proučavanje nastoji pokazati da je doktrina teoze biblijska, povijesna i evanđeoska. U ovom ću članku, pokazati njezinu bibličnost (odnos sa Svetim pismom) kroz određene biblijske tekstove, kao i poveznice sa širom biblijskom pričom. Zatim ću pokazati njezinu povijesnost jer su o njoj pisali kršćanski teolozi od ranog postapostolskog doba (rano 2. stoljeće) pa sve do danas. U sljedećem ću članku pokazati da je to evanđeoska doktrina jer govori radosnu vijest o Isusu Kristu i obnovi ljudske vrste i čitavog stvorenja. Proučavanje ću završiti prijedlogom za evanđeosku doktrinu teoze. 


\section{Glavni biblijski tekstovi za doktrinu teoze}

U ovom ću dijelu ispitivati teozu kroz glavne biblijske tekstove koji se koriste za podršku doktrine. To su: Postanak 1,26-27, Psalam 82,6-7, Ivan 10,34-36 i 2 Petrova 1,4. Ovaj će dio odrediti važne teme koje su povezane s prisvajanjem tih tekstova za teozu. Neću ulaziti duboko u egzegezu svakoga teksta, nego ću se pozabaviti njihovim tumačenjima te na koji su način povezani s konceptom teoze. ${ }^{6}$

\section{Postanak 1,26-27}

Jedan od glavnih tekstova u prilog teozi nalazi se u priči o stvaranju i govori o stvaranju ljudske vrste. Postanak 1,26-27 izjavljuje:

I reče Bog: „Načinimo čovjeka na svoju sliku, sebi slična, da bude gospodar ribama morskim, pticama nebeskim i stoci - svoj zemlji - i svim gmizavcima što puze po zemlji!“ Na svoju sliku stvori Bog čovjeka, na sliku Božju on ga stvori, muško i žensko stvori ih (KS). ${ }^{7}$

Tako je Elohim stvorio adam-a, tako je Theos stvorio anthropos- $a$. Koncept stvaranja ljudske vrste na sliku i sličnost Božju ponavlja se i u drugim biblijskim tekstovima. ${ }^{8}$ Budući da je jedna od važnih stavki teoze obnova Božje slike u kršćanima, slike koja je narušena padom Adama, moramo se pozabaviti ovim izvještajem da bismo razumjeli na koje su načine ljudi stvoreni da budu slični Bogu.

Postanak 1 potvrđuje da je čovječanstvo stvoreno u Imago Dei, implicirajući njihov visok status i vrijednost. No ovaj tekst ne objašnjava što „stvoren na Božju sliku“ znači. Stoga, teolozi su tijekom čitave povijesti Crkve davali mnoga tumačenja (Fretheim 2008, pod „Image of God”). Prema Clossonu, ona se mogu razvrstati u tri temeljne skupine: strukturna, odnosna i funkcijska tumačenja (Closson 2016, pod „Different understandings of the image of God”). Strukturna tumačenja naglašavaju da su ljudi stvoreni na Božju sliku u ontološkom smislu. To se može vidjeti u ljudskoj duhovnosti i razumnosti. Odnosna tumačenja naglašavaju odnosna obilježja. Ljudi su, na primjer, stvoreni da žive u odnosu s Bogom, drugim ljudima i stvorenjem. Funkcijska tumačenja naglašavaju ono što su ljudi stvoreni da čine ili ostvare. Na primjer, dana im je vlast da vladaju stvorenjem i predstavljaju Boga u svijetu. Sve te tri kategorije razdvajaju čovječanstvo od drugih živih bića i svega drugog stvorenja. Ako te kategorije stavimo zajedno,

6 U sljedećem ću se članku baviti drugim biblijskim tekstovima koji upućuju na teozu, poput onih koji govore o kršćanima koji postaju Božja djeca po Kristu i o kršćanima koji se preobražavaju na sliku Krista, koji je slika Boga.

7 Svi su biblijski citati preuzeti iz Biblije u izdanju Kršćanske sadašnjosti, osim ako je drugačije naznačeno. 
možemo reći da „su ljudi poput Boga u tome što su iznimno daroviti intelektualno (i na mnoge druge načine) da bi mogli imati odnos s Bogom i jedni s drugima dok žive kao upravitelji svijeta koji im je Bog dao na upravljanje“ (Turner 1996, par. 3). Teoza obuhvaća obnovu svih tih kategorija kod osobe koju Bog obnavlja i preobražava na svoju sliku.

Biti stvoren na Božju sliku čak obuhvaća činjenicu da je fizičko tijelo nekako stvoreno u odnosu na Božju sliku. Hartley objašnjava hebrejsku pozadinu ovoga gledišta. Oni su promatrali osobu kao cjelinu, bez razdvajanja duha i tijela, a u hebrejskoj Bibliji, kada se Bog ukazivao ljudima u vidljivome, oni su ga prepoznavali u ljudskom obliku (Hartley 2008, 53). Morris ukazuje da Sveta pisma opisuju Boga koji može vidjeti, čuti, mirisati, doticati i govoriti (Morris 1976, 74). Stoga, na neki tajanstven način, čak i ljudsko tijelo odražava Božju sliku. Ovo je važno za doktrinu teoze jer ona tvrdi da će se proces ljudskog pobožavanja završiti kada će tijela kršćanina biti preobražena u slavna, nepokvarljiva i besmrtna tijela (a to su Božje osobine) pri uskrsnuću mrtvih.

Još jedna važna tema za raspravu iz Postanka 1,26 jesu dvije različite riječi koje se koriste kod stvaranja ljudskih bića na temelju Božjeg bića. Jedna je Božja „slika“ (heb. tselem, grč. eikōn), a druga je „sličnost“ (heb. demuth, grč. homoiōsis) Bogu. Postoje različita mišljenja u vezi značenja tih riječi i prepozicija koje dolaze uz njih (Fretheim 2008, pod „C. Meanings and Translations”). Riječi se smatraju dvoznačnima, međusobno zamjenjivima ili istoznačnima u slučaju da se radi o hebrejskom retoričkom sredstvu gdje se sinonimi koriste u svrhu pojačanog dojma). Hartleyjevo razlikovanje je korisno: „'Slika' se odnosi na kopiju ili blisku reprezentaciju... 'Sličnost' naglašava usporedbu jednog objekta s drugim ili podudarnost između dva objekta" (Hartley 2008, 47). Prepozicije također mogu biti dvoznačne - kao sliku Božju ili na sliku Božju - što pruža dva gledišta na ljudska bića: „narav slike (identitet čovjeka; tko čovjek jest) i svrha slike (što čovjek treba biti)“(Fretheim 2008, pod „C. Meanings and Translations”).

Jedna je mogućnost tumačenja da pogledamo u Postanak 1 da bismo vidjeli kakav je Bog te iz toga izvedemo što bi mogla biti njegova sličnost. U priči o stvaranju nalazimo da je Bog razuman, moćan, kreativan, dobar, odnosan i svrhovit. Nadalje, možemo pogledati druge Božje karakteristike, pogotovo one atribute koji su najistaknutiji u njegovim interakcijama s ljudima, kao što vidimo drugdje u Svetom pismu. Bog je svet, vjeran, pravedan i pun ljubavi. Bog želi da i mi budemo takvi, kao što je govorio kroz proroke (npr. „Jer ljubav mi je mila, ne žrtve, poznavanje Boga, ne paljenice”, Hoš 6,6), kroz Isusa Krista (npr. „Budite dakle savršeni kao što je savršen Otac vaš nebeski", Mt 5,48) i kroz novozavjetne autore (npr. „Naprotiv, kao što je svet Onaj koji vas pozva, i vi budite sveti u svemu življenju", 1 Pt 1,15). Sve to važno je za doktrinu teoze, za to da budemo poput Boga. 
U Novom zavjetu za Isusa Krista piše da je „slika Božja“ (2 Kor 4,4), „slika Boga nevidljivoga“ (Kol 1,15) i „odsjaj Slave i otisak Bića njegova“ (Heb 1,3). U prva dva retka grčka riječ je eikōn (slika), u trećem je retku prva riječ apaugasma (odsjaj), a druga je charactēr (otisak). Ideja je da Isus Krist u svom identitetu, naravi i djelovanju pokazuje Božju sliku. Uvod u Ivanovo evanđelje izjavljuje: „Boga nitko nikada ne vidje: Jedinorođenac - Bog... on ga obznani“ (Iv 1,18), dok Isus izjavljuje: „Tko je vidio mene, vidio je i Oca“ (Iv 14,9). Ovo su očigledne tvrdnje o sličnosti između Isusa Krista i Boga. Budući da se kršćani preobražavaju na Kristovu sliku (2 Kor 3,18; Rom 8,29; eikōn), to znači da se preobražavaju na Božju sliku. ${ }^{9}$

Još jedna važna tema za teozu iz ovog teksta iz Postanka je to da je gospodariti ili vladati (heb. radah) dio Božje slike (kakav je Bog i što Bog čini) koja se odražava u čovječanstvu. Proučavanje ovoga glagola „otkriva da se on mora razumijevati u smislu brige i njege, a ne eksploatacije“ (Fretheim 1994, pod „Genesis 1:1-2:3, The Creation”). U Postanku 1,26, Bog kaže samom sebi, govoreći o čovjeku: „neka bude gospoda““ nad životinjama. Sljedeći redak izjavljuje: „Na svoju sliku stvori Bog čovjeka“. Zatim u 1,28 Bog kaže ljudima: „Plodite se, i množite, i napunite zemlju, i sebi je podložite! Vladajte ribama u moru i pticama u zraku i svim živim stvorovima što puze po zemlji." Sve to upućuje da vladavina, aktivnost koju Bog zapovijeda ljudima da obavljaju, jest dio Božje slike u ljudima. „Slika ima funkciju da odražava Boga svijetu, da bude Bog kao što bi Bog bio prema onomu što nije ljudska vrsta, da bude produžetak Božje vlastite vladavine“ (Fretheim 1994, pod „Genesis 1:1-2:3, The Creation”). Bog je vrhovni vladar nad čitavim svemirom i stvorio je čovječanstvo na svoju sliku i sebi slične, da budu vladari nad zemljom. Međutim, padom čovječanstva, ${ }^{10}$ Božja vladarska slika pokvarila se u ljudima, kao što se vidi u Postanku 6,5: „Vidje Jahve kako je čovjekova pokvarenost na zemlji velika i kako je svaka pomisao u njegovoj pameti uvijek samo zloća“.

Ideja čovječanstva, koje je stvoreno na Božju sliku, ključna je za razumijevanje teoze. Značajno je da je čovječanstvo stvoreno isključivo na Božju sliku, a ne na sliku ičega drugog jer teoza se temelji na obnovi tog identiteta. Budući da su stvoreni na Božju sliku i sličnost, ljudi mogu dijeliti određene karakteristike s Bogom. Dijelom su stvoreni zato da bi predstavljali Boga na zemlji i vladali zemljom. Pad čovječanstva iskvario je tu sposobnost. Stoga, obnova Božje slike i sposobnosti za vladanje u kršćanima, kroz Isusa Krista, značajna je za doktrinu

9 Ovom ću se temom detaljnije baviti u sljedećem članku, pišući o teozi u Pavlovoj teologiji.

10 Doktrina o padu čovječanstva dolazi iz Postanka 3 i tvrdi da je ljudski neposluh Bogu donio grijeh i pokvarenost u ljudsku narav i svijet. 
teoze. ${ }^{11}$ U Isusu Kristu Božja je vladarska slika bila savršeno obnovljena. On je pokazivao autoritet i silu, koristeći ih za dobro, za obnovu ljudi. Zbog Isusova djela, Božja vladarska slika nastavlja se obnavljati u ljudima koji vjeruju u njega i slijede njega.

\section{Psalam 82,6-7}

Psalam 82,6 izjavljuje: „Rekoh doduše: 'Vi ste bogovi i svi ste sinovi Višnjega!'“ Ovaj je tekst „citiran nanovo i nanovo kod kasnijih Istočnih Otaca kao onaj koji ukazuje da je konačni cilj spasenja 'postati bogom'“ (Nispel 1999, 292). To je jedini tekst u Bibliji koji izravno ljudska bića naziva bogovima ako se „bogovi“ doista odnosi na ljudska bića. Da bismo ovo protumačili, moramo uzeti u obzir da su Psalmi pjesništvo, književni žanr koji iznosi istine na poseban način, često alegorijski. Ovdje možemo postaviti poznato pitanje s hrvatskih satova književnosti: „Što je pjesnik htio reći?“"12 Također, moramo imati na umu da Isus Krist i novozavjetni autori potvrđuju Psalme kao Božju riječ. Psalam 82 je vapaj za pravdom, gdje Bog donosi presudu u božanskom vijeću ${ }^{13}$ protiv bogova koji sude nepravedno. Presuda je njihova smrt: premda su bogovi, djeca Najuzvišenijega, zbog svoje nepravedne vladavine, umrijet će poput smrtnika. Identitet „bogova“ ključno je pitanje. Različiti komentatori nude različita tumačenja. „Glavna predložena značenja su: manji bogovi i anđeli; nacionalni bogovi pogana; 'zli upravitelji naroda koji drže Izrael u podložnosti' (Briggs, Psalms, II, 215); kraljevi i drugi koji obnašaju vlast; izraelski suci (Targ.)" (McCullough 1980, par. 3).

Ako tumači nude ovaj tekst kao podršku konceptu teoze, obično tvrde da se „bogovi“ odnosi na ljudska bića. Ako bi se „bogovi“ odnosilo na anđele ili bogove kao nebeska duhovna bića, ovaj tekst ne bi se mogao koristiti za teozu. Mnogi komentatori tvrde da se u ovome psalamskom kontekstu „bogovi“ zapravo odnosi na ljudske suce ili vladare - one koji vladaju u Božje ime i na taj način ga zastupaju. ${ }^{14}$ Takvo tumačenje stoga spada u funkcijska tumačenja ljudskih bića kao Božje slike. Neki komentatori pronalaze dodatnu dubinu i značenje u ovoj izjavi. Na primjer, Kirkpatrick piše: “Činjenica da je bilo moguće da ljudi predstavljaju

11 Prema Rakestrawu, glavna definicije teoze je obnova Božje slike u Božjoj djeci, jer je ona narušena padom čovječanstva. Vidi Rakestraw 1997, 261.

12 Ovo pitanje je u Hrvatskoj općekorišten idiom koji obično izražava zbunjenost nečijom izjavom. Potječe od tumačenja poezije na satovima hrvatske književnosti, gdje je to učestalo pitanje, od kojeg često strepe učenici.

13 Ta je slika vjerojatno preuzeta iz kanaanske religije, gdje vrhovni bog El predsjedava vijećem bogova (vidi također $1 \mathrm{Kr}$ 22,19-23; Job 1,6-12; Iz 3,13-15; Hoš 4,1-3; Mih 6,1-5). Vidi McCann, Jr. 1996, par. 1.

14 Vidi, na primjer, Leupold 1974, 592 (Leupold je ovom psalmu dao naslov: Osuda nepravednih sudaca ili vladara); Spurgeon 1988, 415; Wilcock 2001, 42. 
Boga na takav način da budu nazvani bogovima ili božanskima bilo je pretkazanje Utjelovljenja. 'Već se u Zakonu nalazila klica istine koju je Krist objavio, sjedinjenje Boga i čovjeka'“ (Kirkpatrick 1906, pod „Psalm 82:6”).

Psalam 82,6-7 koristio se kao glavni tekst za podršku teoze u patrističkoj teologiji. U svom članku „The Earliest Patristic Interpretations of Psalm 82, Jewish Antecedents, and the Origin of Christian Deification" [Najranija patristička tumačenja Psalma 82, židovski prethodnici i izvor kršćanske deifikacije]. Mosser ispituje tumačenja ovoga teksta kod Justina Mučenika, Ireneja i Klementa Aleksandrijskog. Zaključuje da je za njih glavni značaj psalma proklamacija božanskog sinovstva. Psalam je bio shvaćen kao pretkazanje različitih aspekata Pavlove i Ivanove soteriologije. Štoviše, patristička tumačenja prilagodila su prethodne tradicije koje su iščitavale Ps 82,1.6-7 kao sažetak povijesti spasenja od Adamova pada do eshatološke obnove besmrtnosti i slave koju je izgubio (Mosser 2005, 30).

Drugim riječima, oni nisu preuzeli doslovno tumačenje teksta i riječi „bogovi“ koje zastupa božanskost čovječanstva. Radije, oni su tekst tumačili proročki ${ }^{15}$ na nekoliko načina. Prvo, vjerovali su da tekst opisuje naše stvaranje i pad na vrlo sažet način: Bog nas je stvorio na svoju sliku da budemo njegova djeca (6. redak), ali čovječanstvo je „umrlo“ i „palo“ (7. redak). Također, vjerovali su da je tekst 6 . retka objava našeg otkupljenja, obrat pada u drugom Adamu jer u Kristu možemo ponovno steći besmrtnost i sinovstvo. Vjerovali su da tekst pretkazuje da postajemo Božji sinovi djelom Isusa Krista, kao što to opisuje Pavao. Vjerovali su da tekst također pretkazuje našu obnovu i postajanje Božjom djecom, kao što to opisuje Ivan. Premda se ova tumačenja mogu činiti nategnutima našoj modernoj zapadnoj hermeneutici, Mosser objašnjava da su interpretativna stajališta ovih Otaca Crkve u skladu s judaizmom drugog hrama i židovskim rabinskim spisima (Mosser 2005, 60ff).

Prije nego što napustimo ovaj psalam, još je jedno pitanje važno za naše proučavanje: Kako su ovi oci gledali na izraz „vi ste bogovi“? Mosser izjavljuje da su „patristički pisci rado pripisivali riječ ‘bogovi’ proslavljenim vjernicima, no to su činili na temelju Pavlova učenja da će vjernici biti podignuti u neraspadljivost i besmrtnost (1 Kor 15)“ (Mosser 2005, 73). Drugim riječima, ljudi su bili stvoreni kao „bogovi, djeca Najuzvišenijega“ (6. redak), ali su izgubili tu izvornu slavu i besmrtnost te postali smrtnicima (7. redak). U Pavlovoj soteriologiji, kroz Kristovo djelo, slava i besmrtnost vraćeni su vjernicima. Budući da su slava, neraspadljivost i besmrtnost karakteristike Boga i čovječanstva prije pada, obnova tih karakteristika u ljudima, kroz Krista, također je dio teoze.

15 To znači da su tražili dublje značenje teksta, objašnjenje značaja teksta koje dolazi od Svetog Duha koji otkriva skrivene Božje svrhe koje su van domašaja samoga ljudskog intelekta. 


\section{Ivan 10,34-36}

Ako se „bogovi“ u Psalmu 82,6 odnosi na ljudska bića, u tom slučaju tekst sadrži jasne implikacije za razumijevanje teoze. Nadalje, Isus je citirao taj Psalam u Ivanu 10,34 kada su ga neki Židovi optužili za bogohuljenje jer se izjednačava s Bogom. Isus im je odgovorio: „Nije li pisano u vašem Zakonu: Ja rekoh: bogovi ste! Ako bogovima nazva one kojima je Riječ Božja upravljena - a Pismo se ne može dokinuti - kako onda vi onome kog Otac posveti i posla na svijet možete reći: 'Huliš!' - zbog toga što rekoh: 'Sin sam Božji!'?“ (Iv 10,34-36).

Nekoliko interpretativnih problema javlja se u ovom odlomku. Prvo, tko su „oni kojima je Riječ Božja upravljena“? Govori li Isus općenito o starozavjetnim prorocima koji su primili Božju Riječ? Govori li unutar ili izvan konteksta 82. psalma? Misli li na suce i vladare, što je uobičajeno tumačenje za „bogove“, ili koristi rabinsko tumačenje koje navodi da su to Izraelci kod gore Sinaj?

Nekoliko komentatora zastupa ovo zadnje iščitavanje koje sadrži implikacije za teozu. Mosser tvrdi da je Isus „upućivao na Izrael kod Sinaja (primatelje zapovijedi Zakona), što se shvaćalo kao ponavljanje priče o Adamu i Evi (primatelji izvorne zapovijedi)“( (Mosser 2005, 71). Ackerman objašnjava rabinsko mitološko tumačenje prema kojem je izraelski narod učinjen bogolikim kada im je Bog dao Zakon (Ackerman 1966, 187). "Kada god rabini koriste Ps 82,6-7 izvan konteksta, kao što je to učinio Isus, uvijek se odnosi na Izraelce koji su imenovani bogovima kada su primili zakon kod Sinaja (Ackerman 1966, 188). Tradicija rabinskih zapisa gleda na događaj davanja zakona kod gore Sinaj kao na drugu priliku za besmrtnost čovječanstva, nakon Adamova pada. Nadalje, prema rabinskim tumačenjima, ta je prilika bila kratkotrajna jer su Izraelci napravili zlatnu telad i doživjeli novi pad. Stoga, sljedeća će prilika doći u mesijansko doba (Mosser 2005, 70).

Drugi je problem logika Isusova argumenta jer Židovi ga ne optužuju zbog toga što se naziva bogom, nego Bogom. Kysar izjavljuje: „Premda nam se takav argument čini pogrešnim i zlorabljenjem Pisma, takvo razmišljanje bila je uobičajena rabinska praksa“ (Kysar 1986, 179). O’Day pokazuje da Isus koristi egzegetske tehnike uobičajene za rabinsku argumentaciju u vrijeme prvostoljetnog judaizma (O'Day 1995, pod „10:34-36”). U rabinskom egzegetskom pristupu „može se izvršiti usporedba između dva biblijska teksta već na temelju prisutnosti iste riječi u oba teksta iako se riječi javljaju u različitim kontekstima i prilično različitim značenjima“ (O’Day 1995, pod „10:34-36”). ${ }^{16}$ Stoga, Isus odgovara na rabinski način unutar ove priče.

Neki komentari nude funkcijsko objašnjenje ove tvrdnje na temelju shvaćanja da se „bogovi“ u Psalmu 82,6 odnosi na suce i vladare koji funkcioniraju kao

16 Za više komentara o Isusovoj argumentaciji u ovom tekstu vidi Brown 2008; Brant 2011; Phillips 1989, 405-419. 
Božji predstavnici na zemlji. ${ }^{17}$ No ako je Isus govorio samo funkcijski o svojoj ulozi onoga koji je poslan od Boga, zašto bi ga Židovi htjeli kamenovati? Ivan 10,33 upućuje na više od funkcijskog tumačenja. Židovi su mu rekli „Zbog dobra te djela ne kamenujemo, nego zbog hule: što ti - čovjek - sebe Bogom pravišc‘. Isus završava razgovor s njima tvrdnjom „Otac je u meni i ja u Ocu“ (Ivan 10,38). Stoga, njegovo učenje ima i funkcijsku i ontološku dimenziju.

Naravno, Isus ovdje ne objašnjava doktrinu teoze, nego se brani od optužbe za bogohuljenje. Njegov je fokus primarno na onome tko on jest, i zašto je to što jest, a ne na ontološkom identitetu čovječanstva. No njegove afirmativne izjave o frazi iz Psalma 82,6, da čak i ljudi mogu biti nazvani bogovima, u skladu s Pismom, i dalje su značajne za doktrinu teoze. Nadalje, ako tumačimo tekst Ivana 10,34 u svjetlu prethodno navedenih rabinskih tumačenja „bogova“ u Psalmu 82, Ivanov tekst ima još veću težinu za doktrinu teoze.

\section{Petrova 1,4}

Kao posljednji glavni biblijski tekst u prilog teozi, navodim Drugu Petrovu poslanicu 1,4: „Tim nas je obdario skupocjenim i najvećim obećanim dobrima, da po njima, umaknuvši pokvarenosti koja je zbog opake požude u svijetu, postanete dionici božanske naravi“. Posljednja fraza u ovom retku govori o kršćanima kao dionicima božanske naravi i često se koristi kao još jedan tekst za podršku doktrine o teozi. Ovo su neka ključna pitanja o kojima ću raspravljati: Govori li Petar o budućem dioništvu ili sadašnjem dioništvu? Što misli kada kaže „dionici“? Što misli pod „božanskom naravi“? I što ovaj tekst implicira za kršćansko postojanje i življenje?

Watson izjavljuje da kršćani dobivaju neke ontološke Božje karakteristike i da će to biti buduća stvarnost. Za njega, ta je ideja posuđena iz helenističkog judaizma, da duša koja je pobjegla iz materijalnog svijeta, koji je podložan pokvarenosti zbog požude (zlih želja, 2,10.18-19), ili kod paruzije ili kroz smrt, postiže besmrtnost i neraspadljivost, što su karakteristike Božje naravi i nebeskog svijeta (npr. 4 Mak 18,3; Mudr 2,23; slična ideja nalazi se u Rim 8,18-25; 1 Kor 15,42-57) (Watson 1998, pod „1:4”).

$S$ druge strane, Wolters nudi savezno iščitavanje retka, tvrdeći da fraza nema ništa s „ontološkim sudjelovanjem u Božjem biću“ (Wolters 1990, 30). Izjava se tada može protumačiti kao „partneri s Božanstvom“ i zapravo se odnosi na „vjernikovo partnerstvo s Bogom u savezu" (Wolters 1990, 30). Hafemann isto tako tvrdi da se božanska narav ne odnosi na Božje ontološko postojanje, "nego na Božji dinamički 'karakter izražen u djelovanju' u skladu s njegovim obećanjima.

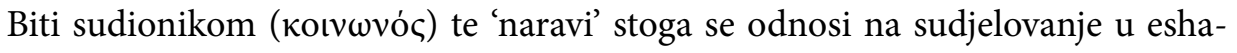


tološkom ostvarenju 'novih nebesa i nove zemlje u kojima prebiva pravednost'“ (Hafemann 2013, 99).

„Božanska narav“ neuobičajen je izraz u Novom zavjetu, no u skladu je s drugim tekstovima gdje vjernici istinski dijele Božji život i osobine. ${ }^{18}$ Neki komentatori ukazuju na to da je taj izraz bio uobičajen u helenističkim filozofijama tog doba, kao što su stoicizam i platonizam, te je možda posuđen od njih (Barclay 1960, 351-352 i Bigg 1956, 256). Dok su poganski filozofi naučavali da su ljudi bili božanski po naravi, Petar je naučavao da ljudi imaju mogućnost sudjelovanja u Božjoj naravi, što se može ostvariti isključivo kroz Krista i po milosti.

Corbin-Reuschling pristupa teozi iz širega konteksta, a to je tekst Druge Petrove poslanice 1,3-1. Za nju, biti dionici znači „zajedništvo, partnerstvo i jedinstvo u svrsi“ i uključuje „sudjelovanje u Božjoj božanskoj naravi i svojstvima“ (Corbin-Reuschling 2014, 279). Ona predlaže da je odgovor na pitanje božanske naravi u Drugoj Petrovoj poslanici 1,4 zapravo popis vrlina u neposrednom kontekstu u 1,5-7 (Corbin-Reuschling 2014, 280). Te su vrline vjera, dobrota, znanje, samokontrola, ustrajnost, pobožnost, privrženost i ljubav - svojstva Božje naravi u kojima mogu sudjelovati kršćani.

Ja bih predložio da Druga Petrova poslanica 1,4 sadrži odjeke teologije o ljudskom stvaranju, padu i novom stvaranju. Da bismo bili dionici božanske naravi, potrebno je da su ljudska bića stvorena na Božju sliku. Pokvarenost u svijetu odražava pad, a autor govori o obratu tog pada. Zbog Božjih obećanja, kršćani izmiču pokvarenosti i mogu sudjelovati u božanskoj naravi. Drugim riječima, Božja je slika obnovljena u njima. To je sadašnja stvarnost, kao što se vidi u nekim prijevodima koji kažu „da po njima možete sudjelovati u božanskoj naravi“ (New International Version) ili „To su obećanja koja vam omogućavaju da sudjelujete u njegovoj božanskoj naravi“ (New Living Translation). U grčkoj konstrukciji îva $\gamma \varepsilon \dot{v} \eta \sigma \theta \varepsilon$ (da biste mogli postati), glagol je u aoristu konjunktivu mediju. Takav odabir riječi dopušta sadašnje razumijevanje jer aorist u konjunktivu ne izražava vrijeme, nego neodređenu akciju (Mounce 2003, 290). Stoga, sada možemo sudjelovati u svojstvima božanskog života koja su navedena u popisu vrlina koji slijedi.

\section{Zaključak u vezi biblijskih tekstova}

Četiri biblijska teksta, koja smo upravo ispitali, mogu se koristiti u prilog teozi. Ta biblijska teologija može se sažeti na sljedeći način: Čovječanstvo je stvoreno na sliku i sličnost Božju (Post 1,26-27), Sveto pismo naziva ljude „bogovima“ (Ps

18 Sudjelovanje u Božjem životu i osobinama ne smije se pobrkati s postajanjem poput Boga u njegovoj biti. Vidi, na primjer, Green 1989, 72-74; MacLaren n.d., 25; Reicke 1964, 153. 
82,6-7), Isus potvrđuje tu izjavu (Iv 10,34-36) i kršćani su nazvani dionicima božanske naravi (2 Pt 1,4). Ti tekstovi ne stoje sami kao podrška teozi. U sljedećem ću dijelu pokazati kako su se ovaj koncept i doktrina razvijali kroz povijest, a u sljedećem ću članku predstaviti novozavjetne tekstove u vezi teoze.

\section{Povijest doktrine o teozi}

Koncept teoze može se pratiti unatrag do nekoliko glavnih utjecaja u grčko-rimskom svijetu: popularna pobožnost, filozofske tradicije te židovska i kršćanska Sveta pisma (Collins 2012, 12). Mjera do koje su kršćanski mislioci prisvojili određene koncepte i terminologiju "predmet je rasprave i tumačenja“ (Collins $2012,12)$. Budući da je ovaj rad fokusiran na biblijsku teologiju teoze, drugi mogući utjecaji, kao što su helenistički platonizam i rabinski judaizam, ovdje se ne obrađuju. ${ }^{19}$ Mene više zanimaju biblijski tekstovi i kršćanska tradicija koji su doprinijeli razvoju doktrine o teozi. $\mathrm{U}$ ovom ću dijelu razmotriti utjecajne vođe rane Crkve i teologe koji se nazivaju crkveni oci patrističkog doba, uključujući apostolske oce, grčke oce i latinske oce. Zatim ću razmotriti utjecajne srednjovjekovne teologe, od ranog do kasnog srednjega vijeka, uključujući mistike, te naposljetku teologe u protestantskim tradicijama i pokretima sve do modernog doba.

\section{Teoza u patrističkoj teologiji}

Doktrina je teoze počela s najranijim glasovima postapostolske Crkve. Apostolski oci, koji pripadaju kasnom 1. stoljeću i razdoblju do srednjeg 2. stoljeća, razrađuju određene teme koje će postati temelj za kasniji razvoj teoze. Na primjer, Ignacije Antiohijski (oko 35. - oko 108.) u svojim pismima raznim crkvama naziva kršćane „donositeljima Boga“, „nositeljima Boga“, onima koji „,sudjeluju u Bogu“, „u potpunosti su od Boga“, „puni su Boga“ i ,imaju Boga u sebi“ (Russell 2004, 91). U svom članku, "Emergence of the Deification Theme in the Apostolic Fathers" [Pojava teme pobožavanja kod Apostolskih otaca], Kharlamov ispituje spise Didahe, Barnabinu poslanicu, Prvu Klementovu, Drugu Klementovu i zapise Ignacija iz Antiohije i Polikarpa iz Smirne. Unutar svog zaključka on izjavljuje: „Sa svojom ekshortacijskom radije nego dogmatskom teologijom, apostolski oci pružaju 'ekonomski' model pobožavanja [koji se temelji na odnosnom aspektu duhovnog života], blisko povezan sa soteriologijom. Imitacija Krista odigrava važnu ulogu kod apostolskih otaca. Biti spašen znači biti poput Krista koliko god je to moguće“" (Kharlamov 2006b, 65). To postajanje poput Krista kasnije će se

19 Za više informacija o izvanbiblijskim utjecajima na teozu, vidi Collins 2012, poglavlje 2. Vidi također Lenz 2008, 47-67. 
promijeniti u postajanje poput Boga, uz određeno izjednačavanje kristifikacije $s$ deifikacijom (Kharlamov 2006b, 52).

Kharlamov dalje ispituje elemente teoze kod apologeta 2. stoljeća, kao što su Justin Mučenik, Tacijan, Teofil Antiohijski i Atenagora Atenski. On pronalazi sljedeće: „Kod Justina, pobožavanje je usporedno s božanskim posinjenjem; kod Teofila, s potpunom zrelošću koja nadilazi izvorno ljudsko stanje" (Kharlamov 2006a, 84-85). Međutim, „Teološka rasprava kod apologeta, izuzev Justina, manje je kristocentrična i eklezijastička u usporedbi s apostolskim ocima. Oni stavljaju veći naglasak na teoretsko razmišljanje koje polaže temelje za ono što će postati tradicionalna metodologija kršćanske teologije“ (Kharlamov 2006a, 84).

Koncept spasenja kao pobožavanja bio je vrlo zastupljen u teologiji ranih grčkih otaca (Nispel 1999, 289; Williams 1999, Kindle lokacija 484). U ovom ću se dijelu usredotočiti na Ireneja i Atanazija. ${ }^{20}$ Irenej je rođen u ranom 2. stoljeću, a umro je krajem 2. ili početkom 3. stoljeća. Bio je biskup Lugdunuma u Galiji (današnji Lyon u Francuskoj), što je bio glavni grad rimske provincije Lugdunumske Galije i važan grad u zapadnoj polovici Rimskog Carstva. Bio je također teolog i apologet koji je značajno pridonio razvoju kršćanske teologije. U drugoj polovici 2. stoljeća, u svom najpoznatijem djelu Protiv krivovjerja, knjiga III, Irenej piše:

U tu je svrhu Riječ Božja bila učinjena čovjekom i On, koji je bio Sin Božji, postao je Sinom Čovječjim, da čovjek, kada je preuzet u Riječ, i primi posinjenje, može postati sinom Božjim. Jer, ničim drugim nismo mogli doći do neraspadljivosti i besmrtnosti, nego da budemo ujedinjeni s neraspadljivošću i besmrtnošću. No kako bismo mogli biti združeni s neraspadljivošću i besmrtnošću, da prvo neraspadljivost i besmrtnost nije postala to što smo mi, tako da raspadljivost može biti progutana neraspadljivošću i smrtnik besmrtnošću, da bismo mogli biti usvojeni kao sinovi? (Irenaeus n.d., 183-184) ${ }^{21}$

Čini se da je Irenej bio prvi crkveni otac koji je izričito artikulirao koncept teoze. Bila je to vodeća tema u njegovim spisima (Russell 2004, 3). On je razdvojio nekoliko ključnih predmeta vezanih uz pobožavanje, o kojima ću raspravljati kasnije u ovom radu: utjelovljenje, usvojenje, sinovstvo, neraspadljivost i besmrtnost. Njegove najpoznatije izjave o pobožavanju dolaze iz djela Protiv krivovjerja, knjiga V: „... slijedeći jedinog istinitoga i stalnog Učitelja, Riječ Božju, naš Gospodin Isus Krist, koji je kroz svoju transcendentnu ljubav postao ono što smo mi,

20 Dvije poznate izjave ovih dvojice ranih otaca često se citiraju u istraživanjima o teozi. Irenej je izjavio da je Krist „postao ono što smo mi, da bi nas mogao dovesti do toga da budemo čak ono što On sam jest“ (Against Heresies, 282), dok je Atanazije izjavio: „On [Krist] postao je čovjekom da bismo mi mogli postati bogom" (On the Incarnation of the Word, 43).

21 Svi citati crkvenih otaca u ovom članku moj su prijevod s engleskog budući da ta djela nisu prevedena na hrvatski s izvornoga starogrčkog jezika. 
da bi nas doveo do toga da budemo čak ono što On sam jest" (Irenaeus n.d., 282). Nekoliko odlomaka dalje, nastavljajući pisati o djelu Isusa Krista, on izjavljuje: „i [Isus] je također izlio Duh Oca za jedinstvo i zajedništvo Boga i čovjeka, doista udjeljujući Boga čovjeku posredstvom Duha i, s druge strane, priključujući čovjeka Bogu vlastitim utjelovljenjem, i darujući nam pri svom dolasku besmrtnost, trajnu i istinsku, posredstvom zajedništva s Bogom" (Irenaeus n.d., 282-283).

Finch otkriva da Irenejeva teologija već sadrži sve temeljne elemente koji se nalaze u budućem patrističkom shvaćanju teoze:

Obnova pred-padne [prije čovjekovog pada] sličnosti Bogu i neraspadljivosti, započeta sjedinjenjem ljudske naravi s božanskom naravi kroz utjelovljenje, život, smrt i uskrsnuće Vječnog Sina, prisvojena egzistencijalno kao usvojenje od Boga i ispunjenje od Duha Svetoga, te konačno vječno usavršena kroz viđenje Boga licem u lice (Finch 2006b, 86-87).

Sudjelovati u božanskoj naravi, prema Finchevu tumačenju Ireneja, ,jest primiti posinjenje od Boga Oca koje se treba asimilirati Bogu Sinu kroz uključenje u čovječanstvo koje je On preuzeo, obnovio, posvetio i prožeo Duhom Svetim pri utjelovljenju“" (Finch 2006b, 103).

Atanazije (296. - 373.) također nosi značajan autoritet kao crkveni otac i teolog. Poput Ireneja, imao je i još uvijek ima vrlo uglednu reputaciju u Crkvi. Bio je biskup u Aleksandriji, jednom od glavnih središta kršćanstva u to vrijeme, i bio je utjecajan sudionik sabora u Niceji. ${ }^{22}$ Njegovo je najpoznatije djelo Utjelovljenje Riječi. U trećem poglavlju piše: „Riječ Božja došla je u vlastitoj Osobi jer jedino je On, kao Slika Oca mogao obnoviti čovjeka stvorenog na Sliku“ (Athanasius n.d., 12). U osmom poglavlju, dok nastavlja pisati o Isusu Kristu kao Riječi Božjoj, izjavljuje: „On je, doista, preuzeo ljudskost da bismo mi mogli postati Bog“ (Athanasius n.d., 43). ${ }^{23}$ Izjave poput ovih sažimaju koncept teoze.

Finch zamjećuje da je teoza središnja ideja u Atanazijevoj teologiji (Finch 2006a, 104). Zaključuje da je Atanazijeva „soteriologija pobožavanja, ili sudjelovanja u božanskoj naravi... bila razvoj i eksplikacija Pavlova i Ivanova naglaska na spasenje kao posinjenje od Boga Oca kroz uključenje po milosti u Boga utjelovljenog Sina“ (Finch 2006a, 121). No kod Atanazija također postoji naglasak na ljudsku suradnju i napor u divinizaciji jer je „na svakom koraku inzistirao da božansko-ljudsku razmjenu utjelovljenja mora prisvojiti svaki pojedinac kroz poslušno imitiranje Krista, asketske prakse i primanje sakramenata“ (Finch 2006a,

22 Vrlo značajan ekumenski sabor u povijesti Crkve, održan u gradu Niceji 325. godine. Riješio je pitanje Kristova božanstva i iznio Nicejsko vjerovanje. To je izjava vjere koju prihvaćaju gotovo sve kršćanske denominacije.

23 Rečenica se može javljati u blagim varijacijama, ovisno o prijevodu s grčkog (Aủtò $\gamma$ $\grave{\alpha} \rho$

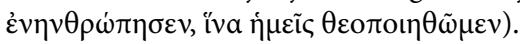


110). Prema tomu, Atanazije je također bio jedan od prvih crkvenih teologa koji je opisao na koji način osobe Trojstva pridonose teozi (McGinn 2006, 400). To je važna tema koja će se obrađivati kasnije u ovom radu.

Osim ova dva istaknuta lika, mnogi drugi crkveni oci pisali su o pobožavanju. Aleksandrijska je kršćanska misao dala značajan doprinos teozi. Na primjer, Klement Aleksandrijski (oko 150. - oko 215.) prvi je upotrijebio glagol theopoiein (učiniti bogom, pobožiti) u kršćanskom spisu (McGinn 2006, 398). Origen Aleksandrijski (oko 185. - oko 254.), još jedan istaknuti autor, napisao je:

No i sam Isus i njegovi učenici željeli su da njegovi sljedbenici ne vjeruju samo u njegovo božanstvo i čuda, kao da nije također bio dionik ljudske naravi, preuzevši ljudsko tijelo koje „žudi protiv Duha“; no oni su također vidjeli da je sila, koja je sišla u ljudsku narav, i usred ljudskih jada, i koja je preuzela ljudsku dušu i tijelo, da je doprinijela po vjeri, zajedno s njezinim božanskim svojstvima, spasenju vjernika, kada vide da je od Njega počelo sjedinjenje božanske s ljudskom naravi, da bi se čovjek, kroz zajedništvo s božanskim, mogao uzdići da bude božanski, ne samo u Isusu nego u svima onima koji ne samo da vjeruju nego i ulaze u život koji je Isus naučavao, i koja podiže u prijateljstvo s Bogom i zajedništvo s njim svakoga koji živi po Isusovim načelima (Origen n.d., 65).

Prema Origenu, kršćanski bi život trebao biti više od vjerovanja u Boga i njegova čuda. Trebao bi biti sjedinjenje ljudskoga s božanskim zbog onoga što je omogućio Isus.

Russell je posebno posvetio pažnju aleksandrincima. Sažimajući svoje pronalaske o tezi, on izjavljuje:

... Aleksandrinci su koristili metaforu pobožavanja da bi ukazali na slavnu sudbinu koja očekuje ljudsku narav u skladu s božanskim planom spasenja. Temeljni „moment“ je kada Logos pobožava reprezentativnu ljudsku narav koju je primio pri Utjelovljenju. To nosi određene implikacije za pojedina ljudska bića. Vjernik može sudjelovati u poboženom Kristovu tijelu - Gospodinovoj uzvišenoj ljudskosti - kroz krštenje, euharistiju i moralno življenje. Takvo sudjelovanje dovodi do pobožavanja, ne kao privatnog mističkog iskustva nego kao preobrazbe koja se događa unutar crkvenog tijela (Russell 2004, 205). ${ }^{24}$

Kapadocijski oci ${ }^{25}$ 4. stoljeća, Bazilije Veliki, Grgur iz Nise i Grgur Nazijanski,

24 Russellovo monumentalno djelo The Doctrine of Deification in the Greek Patristic Tradition [Doktrina pobožavanja u grčkoj patrističkoj tradiciji] rezultat je gotovo dvadeset godina proučavanja pobožavanja u patrističkoj teologiji. On razotkriva zapise o pobožavanju kod apostolskih otaca, grčkih otaca, latinskih otaca i sirijskih otaca.

25 Također, nazivaju se Tri Kapadocijanca, prema rimskoj i bizantskoj provinciji Kapadociji u Maloj Aziji. 
također su pisali o teozi. Grgur Nazijanski je bio nadbiskup (patrijarh) Konstantinopola. Smislio je termin teoza ( $\theta \dot{\varepsilon} \omega \sigma \iota \varsigma)$ i srodni glagol theoō ( $\theta \varepsilon$ có $\omega$ ) (Russell 2004, 249). Russell izjavljuje da kapadocijski teolozi „preuzimaju doktrinu pobožavanja od aleksandrinaca i prilagođavaju je platonističkom shvaćanju kršćanstva kao postizanja sličnosti Bogu koliko god je to moguće za ljudsku narav“ (Russell 2004, 232). ${ }^{26}$

Koncept teoze također se može naći u spisima latinskih ili zapadnih crkvenih otaca. Tertulijan (oko 155. - oko 240.) je bio prvi latinski teolog koji je pisao o teozi (Collins 2012, 61). Augustin (354. - 430.), jedan od najpoznatijih latinskih crkvenih otaca i jedan od najistaknutijih teologa u razvoju zapadnog kršćanstva, također se bavio ovom doktrinom. Augustin je rijetko, ali izričito govorio o pobožavanju. Upotrijebio je latinski termin deificare, što znači „pobožavati“. Na primjer, u ekspoziciji Psalma 50, on povlači argument iz Psalma 82,6-7 te izjavljuje:

Očito je, stoga, da je On nazvao ljude bogovima, one koji su poboženi njegovom milošću, a ne rođeni od njegove biti. On opravdava jer je pravedan sam po sebi i ne po drugome; i on pobožava jer je sam po sebi Bog, ne sudjelovanjem nekoga drugoga. No On, koji opravdava i sam pobožava, jer po opravdanju On čini sinove Božje. „Jer, On im je dao vlast da postanu sinovi Božji", Ivan 1,12. Ako smo učinjeni sinovima Božjim, također smo učinjeni bogovima: ali to je učinak milosti koja nas posvaja, a ne naravi koja stvara (Augustine 2007, 315).

Jezik teoze također se nalazi u nekim Augustinovim propovijedima. On propovijeda: „Bog, vidite, želi vas učiniti bogom; ne po naravi, naravno, poput onoga koga je on rodio; nego po njegovu daru i po usvajanju. Jer, kao što se On ponizio da bi s vama dijelio vašu smrtnost; tako vas kroz uzdizanje dovodi do toga da s njim dijelite njegovu besmrtnost“ (Augustine 1992, 209). Novije teološko istraživanje smatra da je teoza jedna od glavnih Augustinovih metafora za kršćanski život. Suprotno mnogim prethodnim učenjima o Augustinu, Meconi tvrdi:

Pobožavanje ljudske osobe je ključno za način na koji sv. Augustin predstavlja kršćaninov novi život u Kristu. Augustin, stoga, predstavlja kršćanski život u okvirima Božjeg Sina koji je postao čovjekom, da bi ljudi mogli postati Bogom. To transformativno sjedinjenje dopušta biskupu iz Hipona da ovako potiče svoju zajednicu: „Radujemo se stoga i zahvaljujmo jer nismo učinjeni kršćanima, nego smo učinjeni Kristom“ (Meconi 2013, xi).

Izdavačev opis knjige pruža pronicljiv sažetak Meconijeva istraživanja Augustinove teologije teoze:

Provokativnih odlomaka o pobožavanju ima u izobilju kod sv. Augustina iz 
Hipona. On se oslanja na izraz „pobožavanje“ daleko više od drugih latinskih očeva. Ono što je još važnije, stvarnost poboženog života proteže se kroz svaki glavni aspekt Augustinova predstavljanja kršćanstva... Za Augustina, kršćanski život u biti je uključenje izabranih u samu Kristovu osobu... gdje Krist i kršćanin postaju jedno kroz milost Svetog Duha i crkvene sakramente, koji uzdižu muškarce i žene i omogućavaju im da sudjeluju u Božjem vlastitu životu... jedino ljudska osoba nosi imago Dei, i javlja se kao ona koja je pozvana da slobodno prisvoji Božji život. Za tu svrhu, Sin je postao čovjekom (Meconi 2013, izdavačev opis knjige).

Williams ističe da Augustinovo pisanje o pobožavanju „daleko više odražava raniju i kasniju teologiju nego ono što smo pronašli kod Kapadocijanaca. Pozivajući se na sveprisutni Psalam 82, on govori o pobožavanju po milosti, pažljivo to razdvajajući od posjedovanja božanske biti. On, također, pravi razliku između Onoga koji pobožava i onih koji primaju poboženje“ (Williams 1999, Kindle lokacija 533). Puchniak sažima svoje istraživanje teoze u Augustinovu radu: „Augustin je podsjetio ljude da je pobožavanje božanski dana mogućnost, crkvena u svojim dimenzijama, i telos sadašnjih težnji“ (Puchniak 2006, 132).

Do sada, zabilježili smo dosta crkvenih otaca i njihov doprinos teozi. Razmotrimo sada nekoliko odlomaka koji nastoje sažeti koncept i doktrinu teoze tijekom patrističkog doba. Collins nudi sljedeći sažetak:

Pet je temeljnih elemenata koji su se koristili u patrističko doba da bi izrazili metaforu pobožavanja. Tri su para suprotnosti i dva su para iz filozofskih/ teoloških tradicija. Parovi suprotnosti su: nestvoreno i stvoreno, besmrtno i smrtno, božansko i ljudsko, a parovi koncepata su slika i sličnost te ousia [bit] i energeia [energija]. Koncept pobožavanja također je konstruiran oko različitih formula. Filozofska tradicija drevne Grčke pruža ih barem tri: (1) imitacija božanskoga, (2) sudjelovanje u božanskom i (3) uzdizanje duše do božanskoga. Svaki od njih povezan je s parom besmrtno-smrtno. Imitacija je u bliskom odnosu s prakticiranjem vrlina. Sudjelovanje i uzdizanje povezani su s konceptom kontemplacije ili njihove kontemplacije ili theoria [vizije], što ukazuje na susret s božanskom svjetlošću (Collins 2012, 49-50).

Nakon opsežne obrade crkvenih otaca i teoze u prvom dijelu svoje knjige, Williams pruža ovaj vrijedan sažetak patrističke teologije pobožavanja:

Ovo je, dakle, patristička tradicija pobožavanja. Premda nalazimo malo stvarnih definicija tog termina, javlja se dovoljno jasan obrazac da možemo iznijeti neke općenitosti. On utvrđuje da su Imago Dei i Utjelovljenje temelji pobožavanja i konstruira teozu uglavnom u terminima znanja, vrline, svjetlosti i slave, sudjelovanja i sjedinjenja. Kod nekih autora, sakramenti su važni posrednici divinizacije; a češće se značaj pridaje ljudskim svojstvima poput intelekta i sposobnosti za ljubav. Iako naglasak na tjelesnoj dimenziji varira, postoji široki konsenzus da sudjelovanje u božanskoj naravi obuhvaća tjelesnu neraspad- 
ljivost. Iznad svega, oci upućuju na razlikovanje nestvorenoga i stvorenoga, zajedno sa željom Stvoritelja da njegova stvorenja sudjeluju u njegovu vlastitu životu i dobroti. Stoga, teoza, iako sadrži određeni stupanj ljudskog nastojanja ka kreposnoj asimilaciji u Boga i Božju ljubav, uvijek ostaje božanski dar, dar milosti. Ideja neobustavljene progresije prema Bogu, neprekinutosti između ovog života i sljedećeg, javlja se u djelima većine Otaca, ali nagovještaji teoze u njezinoj punini koja cvjeta u ovom životu su rijetki (Williams 1999, Kindle lokacija 573-579).

Mannermaa izjavljuje da se temeljna ideja patrističkog shvaćanja teoze može ukratko opisati na ovaj način: „Božanski život manifestirao se u Kristu. U Crkvi, koja se shvaća kao Kristovo Tijelo, ljudska bića sudjeluju u tom životu i time su dionici 'božanske naravi’ (2 Pt 1,4). Ta "narav“, ili božanski život, prožima postojanje ljudskih bića kao što kvasac prožima kruh, da bi ga vratio u njegovo izvorno stanje kao imago Dei" (Mannermaa 1998, Kindle lokacije 327-329).

Stoga, u patrističkom dobu važno je zamijetiti da je pronađeno nekoliko elemenata doktrine teoze u spisima kršćanskih zajednica po čitavom kršćanskom svijetu, zajednica koje su govorile grčki, latinski, sirijski, koptički i kaldejski jezik (Collins 2012, 60). Prema Collinsu: „Moguće je vidjeti zajedničku nit, koja se proteže preko različitih jezičnih zajednica, izraženu u konceptualnosti razmjene koju koristi Irenej. Božji je sin postao ljudskim bićem, da bi ljudska bića mogla postati božanska“" (Collins 2012, 60).

\section{Teoza u srednjovjekovnoj teologiji}

U ranom srednjem vijeku prvo vidimo smanjen naglasak na teologiju teoze, nakon čega slijedi oštro povećanje na kraju tog razdoblja. Collins objašnjava tu pojavu:

Do kasnog 5. stoljeća jezik pobožavanja i njegova temeljna konceptualnost nisu se puno koristili u teološkim raspravama jer priziv na pobožavanje, kao metafora spasenja, više nije bio u modi. Razlog tomu većinom se može naći u sumnji koja je okružila učenja Origena i onih koji su oblikovali teološko promišljanje na sličan način“ (Collins 2012, 102).

Međutim, početkom 6. stoljeća utjecaj Dionizija Areopagita ${ }^{27}$ uzrokovao je povećanu pozornost na teozu. Njegovi spisi „doveli su konceptualnost pobožavanja u glavni tok teološke rasprave“ (Collins 2012, 106). Dionizije je bio prvi kršćanski teolog koji je oblikovao definiciju teoze, tek u 6. stoljeću poslije Krista. Ona izjavljuje: „Asimilacija u Boga i sjedinjenje s Bogom, koliko god je to moguće postići,

27 Ovaj značajni teolog preuzeo je ime Pavlova atenskog obraćenika iz Djela 17,34. Zbog toga ga se također identificira kao Pseudo-Dionizije Areopagit ili Pseudo-Denys. Njegov je identitet osporavan, ali njegova su djela dobro dokumentirana i datirana. 
jest pobožavanje“ (Dionysius the Areopagite 1897, 189). Dionizije je također zaslužan za popularizaciju termina "teoza“ (Williams 1999, Kindle lokacija 544). ${ }^{28}$

U 7. stoljeću Maksim Ispovjednik (oko 580. - 662.) pojavio se kao glavni teolog koji se bavio teozom. Njegovi su doprinosi značajni. Prvi put je predstavio doktrinu teoze kao samostalnu. Ne samo da ju je izrazio kao metaforu spasenja nego i kao svrhu stvaranja čovječanstva te ju je utvrdio kao temeljnu doktrinu istočnog pravoslavlja (Collins 2012, 106-108). Russell tvrdi: „Irenejsko i aleksandrijsko načelo da je Bog postao čovjekom da bi čovjek mogao postati bogom prima u njegovim [Maksimovim] rukama svoju najveću elaboraciju i najdublju artikulaciju“" (Russell 2004, 262). Jedan izvadak iz Maksimovih spisa o teozi kaže:

Sigurno jamstvo za gledati s nadom pobožavanje ljudske naravi pruženo je Božjim utjelovljenjem, što čini čovjeka bogom do istog stupnja do kojega je sam Bog postao čovjekom. Jer, jasno je da će On, koji je postao čovjekom bez grijeha (usp. Heb 4,15), pobožiti ljudsku narav a da je ne promijeni u božansku narav, i da će je uzdići radi sebe samoga do istoga stupnja do kojega se ponizio radi čovjeka samoga (Maximus 2015, Kindle lokacija 2513).

Russell sažima Maksimovu teologiju pobožavanja na sljedeći način:

Nakon kenoze Riječi slijedi teoza vjernika, nakon Božje prilagodbe suženosti ljudskog života, slijedi čovjekovo proširenje, unutar ograničenja njegovih mogućnosti kao stvorenja, do beskraja božanskog života. Pobožavanje nije samo još jedan izraz za spasenje, popravak štete učinjene grijehom. Ono je konačna svrha spasenja, postizanje sudbine koja je izvorno namijenjena čovječanstvu, koju je Adam u svojim rukama i odbacio. Ono se može očekivati do nekog stupnja u ovom životu, ali svoje ispunjenje postiže u sljedećem životu, u najpotpunijem mogućem sjedinjenju s utjelovljenom Riječi. Ne uključuje samo čovjeka nego i čitav njegov svijet. Jer, pobožavanje je na kraju cilj, skopos, čitavog kozmosa (Russell 2004, 262). ${ }^{29}$

Važan doprinos teozi dolazi od Ivana Damaščanskog (oko 676. - 750.), ${ }^{30}$ koji „postavlja teološku antropologiju u kojoj se pobožavanje shvaća kao cilj ljudskoga života" (Collins 2012, 109). Prema Collinsu, posljednja tri spomenuta teologa (Dionizije, Maksim i Ivan) „,imali su ogroman utjecaj na prihvaćanje te tradicije unutar istočnog kršćanstva“ (Collins 2012, 109). Značajan razvoj u rano srednjovjekovno doba je to što je doktrina teoze, koja je bila izražena metaforički u prvih nekoliko stoljeća, sada izražena „konceptualno i dogmatički“ (Russell 2004, 1).

Za grčki vokabular pobožavanja, vidi Russell 2004, dodatak 2. On zaključuje da „kršćanski autori po-

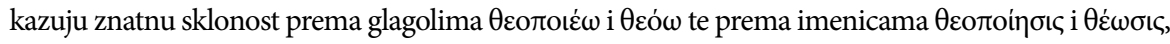
a obje su imenice kasne kovanice i nalazimo ih gotovo isključivo kod kršćanskih pisaca“" (343).

29 Za detaljniju analizu teoze kod Maksima, vidi Vishnevskaya 2006, 134-145.

30 Ivan Damaščanski je posljednji od takozvanih grčkih otaca. 
Nakon Velikog raskola 1054. godine, kad su se zapadne crkve odvojile od istočnih crkava, doktrina teoze tijekom srednjeg i kasnoga srednjovjekovnog doba i dalje se može vidjeti. U tom razdoblju, najistaknutiji i najutjecajniji teolog zapadne Crkve bio je Toma Akvinski (1225. - 1274.), dok je u istočnoj Crkvi to bio Grgur Palama (1296. - 1359.). A. N. Williams opsežno je analizirala doprinose ovih dvojice teologa u svojoj knjizi The Ground of Union: Deification in Aquinas and Palamas [Temelj jedinstva: pobožavanje kod Akvinskog i Palame]. Williams ispituje tekstove gdje Akvinski govori izravno o pobožavanju (ili suobličenju, sudjelovanju, jedinstvu) te o implikacijama u njegovoj teologiji, antropologiji, epistemologiji, kristologiji, etici itd. Ona zaključuje da Akvinski „uzima teozu zdravo za gotovo i pretpostavlja da će njegovi čitatelji učiniti isto" (Williams 1999, Kindle lokacija 1652) te da „teologija Summe oslikava Boga koji namjerava privući stvorenja u vlastiti život" (Williams 1999, Kindle lokacija 1033). ${ }^{31} \mathrm{U}$ njezinu tretmanu Božje slike i sličnosti, ona izjavljuje da „Akvinski ovdje prati proces postizanja sličnosti Bogu u tri koraka, od sličnosti koja je utisnuta u našu narav, preko sličnosti koja se povećava u ovom životu po milosti, do sličnosti u sljedećem životu, kada će ljudska imitacija znanja i ljubavi Trojstva biti usavršena“ (Williams 1999, Kindle lokacija 1325). U zaključku: „Stoga, gledati na Boga znači razumjeti i ono što jesmo i ono što trebamo biti, i naše prirodno stanje i ono što trebamo postati“ (Williams 1999, Kindle lokacija 1341).

Teologija Grgura Palame imala je golemi utjecaj na Pravoslavnu Crkvu, naročito njegova doktrina teoze. Pravoslavna Crkva smatra ga „besprijekornim zapisničarom duge tradicije, misliocem koji okuplja nizove koji se protežu unatrag skroz do Ireneja, dajući im njihov koherentni, autoritativni i konačan izričaj“ (Williams 1999, Kindle lokacija 2653). Williams pronalazi da Palama dosljedno koristi deset slika kako bi opisao teozu: „prve tri (vrlina, znanje i vizija) predstavljaju temelje pobožavanja, dok su sljedeće četiri (kontemplacija, svjetlost, milost i slava) gotovo istoznačne, a tri (usvojenje, sudjelovanje i sjedinjenje) zapravo djeluju kao sinonimi pobožavanju“ (Williams 1999, Kindle lokacija 1981-1982). U Palaminim spisima o milosti Williams pronalazi „glavno načelo teoze: darivanje božanskog dara preobražava primatelja i kroz tu preobrazbu ostvaruje se sličnost Bogu koja jedina može omogućiti istinsko zajedništvo" (Williams 1999, Kindle lokacija 2359).

Palama je najpoznatiji po svojoj teološkoj poanti razlikovanja božanske biti i božanskih energija, ${ }^{32}$ što je njegov način objašnjavanja kako je moguće sjedinje-

31 Summa Theologiae Tome Akvinskog je njegovo najpoznatije i iznimno utjecajno djelo.

32 Williams vjeruje da je to razlikovanje u Palaminim spisima tek nominalno, a ne stvarno (Williams 1999, Kindle lokacija 2687). Međutim, većina teologa tumači razlikovanje u palamističkoj misli kao stvarno, a samo nekolicina smatra da je nominalno. Razlikovanje biti i energija također je predmet rasprave između zapadnih i istočnih teologa. 
nje između nestvorenog božanskog bića i stvorenoga ljudskog bića, a da se ne brišu granice između ta dva bića. Bog ostaje odvojen u svojoj biti, a kroz svoje energije ostvaruje zajedništvo s ljudskim bićima. Božja je bit njegovo biće, a njegove su energije one stvari po kojima djeluje u svijetu. Božje energije su, na primjer, sila, ljubav, milost itd. Prema Losskyju, milost je drugi naziv za „energije pobožavanja koje nam prenosi Sveti Duh" (Lossky 2002, 86). Mi možemo sudjelovati u njegovim energijama, ali ne u njegovoj biti. Bog je transcendentan u svojoj biti i imanentan u svojim energijama (Cheng n.d., 98). Božja je bit nepristupačna, neraspoloživa i neparticipativna za nas, dok su njegove energije pristupačne, raspoložive i participativne za nas. Međutim, to ne znači da je Bog na neki način podijeljen u dva dijela, kao što kaže ovdje: „Iako je u potpunosti nespoznatljiv u svojoj biti, Bog u potpunosti otkriva sebe u svojim energijama, koje ni na koji način ne dijele njegovu narav na dva dijela - spoznatljivu i nespoznatljivu - nego predstavljaju dva različita načina božanskog postojanja, unutar biti i izvan biti“ (Lossky 2002, 86).

U svom istraživanju o teozi u spisima crkvenih otaca, Tome i Grgura, Williams zaključuje: „Ne samo temeljni načini opisivanja divinizacije nego i većina konkretnih slika i koncepata koji se koriste za to podudaraju se u djelima Očeva, Akvinskog i Palame“ (Williams 1999, Kindle lokacija 3129). Ona izlaže još jedan značajan zaključak, da je teoza za svakog kršćanina: „Jedna važna suglasnost kod svih tih pisaca je da nijedan ne govori o onome što bismo primjereno nazvali mističkim iskustvom - to jest, izvanredna spoznaja ograničena na nekolicinu posebno svetih osoba. Ovi autori predstavljaju sjedinjenje koje pobožava, za razliku od mističkog ushićenja, kao standard kršćanskog rasta u Boga“ (Williams 1999, Kindle lokacija 3138).

Dok je teoza postala glavna i temeljna doktrina u istočnoj teologiji, nasuprot tome postala je marginalizirana u zapadnoj teologiji. Collins analizira elemente metafore pobožavanja na Zapadu i zaključuje da ta doktrina nije zauzela važno mjesto, ali pronalazi „stalne tragove... i unutar glavnih tradicija i unutar onih koje su smatrane 'rubnim' tradicijama" (Collins 2012, 111). Elementi pobožavanja također postoje kod skolastika i mistika.

Jedan od glavnih predstavnika skolastike ${ }^{33}$ je Toma Akvinski. Poput Williams, Collins zaključuje da Akvinski „koristi jezik i slikovit govor patrističkog izvještaja o pobožavanju“ (Collins 2012, 117). U zaključku svog istraživanja skolastika, Collins piše:

Istraživanje metafore pobožavanja u srednjovjekovnoj „mističkoj teologiji“ u školama i sveučilištima uglavnom se fokusira na uzdizanje duše ka Bogu

33 Skolastika je „sustav i metoda učenja filozofije i teologije tijekom srednjovjekovnog razdoblja koja se razvila u kontekstu europskih sveučilišta. Oslanjala se na filozofske metode i korištenje razuma da bi odredila jasne podjele i razlike unutar skupa znanja“ (McKim 1996, 250). 
i postizanje mističkog sjedinjenja. Ovo nije postavljeno tek na kategorijama platonizma nego je također konstruirano oko priziva na „formulu razmjene“ i stoga ukorijenjeno u Utjelovljenju. Metafora se istražuje u okvirima posinjenja: postojanje „u Kristu“ postignuto kroz sudjelovanje u sakramentima krštenja i euharistije. Elementi metafore povezani su s procesom posvećenja i uključuju doktrine o Svetom Duhu i milosti (Collins 2012, 120-121).

Analizirajući elemente pobožavanja u mističkoj teologiji, Collins također istražuje mistike kao što su Bernard iz Clairvauxa, Meister Eckhart, Julijana iz Norwicha, Terezija Avilska i Ivan od Križa. Collins zaključuje sljedeće:

Spisi srednjovjekovnih i ranih modernih mistika slijede klasičan obrazac procesa božansko-ljudskog sjedinjenja: pročišćenje, prosvjetljene i pobožavanje. Duša, koja je očišćena od grijeha kroz krštenje i živi dobrim moralnim životom, vožena je u duboko i intimno zajedništvo s Bogom otpuštajući svoju volju i egoistične želje, uzdižući se iznad svih stvorenja u svijetu i okrećući se unutra u stanje nutarnjeg jedinstva, smirenosti i tihe kontemplacije. Nekoliko tih autora crpi ne samo iz osobnoga mističkog iskustva nego također iz iskustva patnje neke vrste koja pridonosi i možda „omogućava“ mističko iskustvo koje imaju (Collins 2012, 136-137).

\section{Teoza u protestantskim tradicijama}

Isti nedostatak naglaska na teozu u zapadnoj Crkvi može se zamijetiti u protestantskim tradicijama. Teoza nije bila oblikovana kao cjelovita doktrina niti je zauzimala važno mjesto u teologiji. No elementi doktrine nalaze se kod glavnih teologa i pokreta kao i kod marginalnih tradicija. Čini se da teoza ne odigrava izričitu ulogu u pet protestantskih solae (sola scriptura, sola fide, sola gratia, solus Christus, soli Deo gloria) niti u ideji svećenstva svih vjernika. Prema Collinsu, postoji pretpostavljeni problem nekompatibilnosti između teoze i doktrina o opravdanju i milosti, koji se „temelji na shvaćanju da je doktrina pobožavanja konstruirana oko ideja božansko-ljudske 'sličnosti' i sinergije volja, koje se smatraju 'nemogućima' u okviru protestantskog shvaćanja Božje svetosti i grešnosti ljudske osobe“ (Collins 2012, 145).

Martin Luther (1483. - 1546.) bio je začetnik protestantske reformacije i veliki protestantski teolog. Ideologija teoze nalazi se u nekim Luterovim propovijedima. Na primjer, u ovom izvatku iz propovijedi, u kojoj Luther govori na temelju Poslanice Efežanima 3,13-21, on objašnjava što znači biti ispunjen svom Božjom puninom:

... ispunjen svime što Božje obilje pruža, pun Boga, ukrašen njegovom milošću i darovima njegova Duha - Duha koji nam daje postojanost, prosvjetljava nas svojom svjetlošću, živi u nama svoj život, spašava nas svojim spasenjem i svojom ljubavlju rasplamsava ljubav u nama; ukratko, to znači imati samoga Boga i sve njegove blagoslove da prebivaju u nama u punini i da nas učinko- 
vito čine potpuno božanskima - ne da bismo posjedovali tek nešto od Boga nego svu njegovu puninu (Lenker n.d., 236).

Lutherove glavne teološke teme često su bile opravdanje i milost, što neki teolozi smatraju nespojivim s teozom (Mannermaa 1998, Kindle lokacije 320-321). Drugi nude drugačije tumačenje. Na primjer, jedno od tradicionalnih tumačenja Lutherove doktrine o opravdanju je legalistički sudski pristup, gdje Bog proglašava osobu pravednom na temelju otkupljenja, milosti koju je providio Krist, i na temelju vjere te osobe $\mathrm{u}$ Krista. Osobu se tada smatra pokrivenom Kristovom krvlju, grešnikom koji je opravdan milošću po vjeri. To ostaje glavnom doktrinom luteranizma, temelj doktrine spasenja samo milošću, samo po vjeri i samo u Kristu. Točka prijepora u pogledu teoze je to što učenje o pravednosti dolazi izvana i ostaje izvana - to je Kristova pravednost pripisana vjerniku, ali ne i usađena. Stoga, osoba ostaje grešnikom koji je spašen milošću. Međutim, drugačije i novije tumačenje Luthera izjavljuje da „za Luthera vjera je stvarno sudjelovanje u Kristu, gdje u vjeri vjernik prima Božju pravednost u Kristu, ne samo nominalno i izvanjski nego stvarno i iznutra" (Braaten i Jenson 1998, Kindle lokacije 25-26).

Izmijenjena tumačenja, kao što je ovo, pružaju bliskiju vezu s pravoslavnim razumijevanjem teoze. „Pravednost kao Božje svojstvo u Kristu ne može se odvojiti od njegova božanskog bića. Stoga, Luther je smatrao prikladnim reći da se po vjeri u Krista događa stvarna razmjena, Božja pravednost razmijenjena za grešnost ljudskih bića. Božja pravednost koja vjerom postaje naša pa je stvarno sudjelovanje u Božjem životu“ (Braaten i Jenson 1998, Kindle lokacije 28-30). Zastupnici ovoga gledišta su i Tuomo Mannermaa i njegova finska škola. ${ }^{34} \mathrm{Ma}$ nnermaa izjavljuje: „Središte Lutherove teologije je da u vjeri ljudsko biće stvarno sudjeluje po vjeri u osobi Krista i u božanskom životu i u pobjedi koja je u njemu. Ili, da kažemo na drugi način: Krist daje svoju osobu ljudskom biću po vjeri po kojoj to primamo“ (Mannermaa 1998, Kindle lokacija 396-398). Mannermaa nastavlja objašnjavati da zbog toga što vjernici sudjeluju u Kristu, oni sudjeluju u božanskom životu, u Božjoj punini, u Božjoj naravi, to jest, u Božjoj biti koja sadrži Božja svojstva kao što su „pravednost, mudrost, sila, svetost, radost, mir, vječni život - a naročito ljubav“ (Mannermaa 1998, Kindle lokacija 434).

Osim glavnih protestantskih reformatora i crkava, možemo razmotriti i druge crkve i pokrete nastale u ili iz reformacije. Prateći trag teoze u zapadnoj teologiji, Collins dalje piše o pokretu radikalne reformacije (kao što su anabaptisti i menoniti u 16. stoljeću), engleskoj reformaciji (16. stoljeće), Velikom probuđenju

34 Tuomo Mannermaa (1937 - 2015) bio je profesor emeritus ekumenske teologije na Helsinškom sveučilištu u Finskoj. Bio je međunarodno prepoznat teolog o Lutheru i voditelj „Novog finskog tumačenja Luthera" koje tvrdi da su Lutherova gledišta o spasenju bliža pravoslavnoj doktrini teoze nego protestantskom sudskom opravdanju. 
(18. i 19. stoljeće), Oksfordskom pokretu (19. stoljeće) i Pokretu svetosti (19. i 20. stoljeće). Radikalna reformacija razvila je shvaćanje spasenja koje obuhvaća stvarnu pravednost, sjedinjenje s božanskim i sudjelovanje u božanskoj naravi (Collins 2012, 151-152). Neki teolozi u Anglikanskoj Crkvi koristili su metaforu pobožavanja. „Oni svjedoče o konstantnom prihvaćanju pobožavanja unutar konteksta engleske reformacije, što se unijelo u pokrete probuđenja 18. i 19. stoljeća" (Collins 2012, 152-155, 156).

U razdoblju Velikog probuđenja također nalazimo djela Johna Wesleyja i njegove nauke o kršćanskom savršenstvu ${ }^{35}$ i potpunom posvećenju, ${ }^{36}$ „koje je on shvaćao kao kretanje prema konačnom jedinstvu s Bogom“ (Collins 2012, 159). Vođe Oksfordskog pokreta ${ }^{37}$ ponovno su otkrili doktrinu teoze iz starijih tradicija i promicali je kao eklezijalnu, sakramentalnu i zajedničku doktrinu (Collins 2012, 159-163). Pokret svetosti ${ }^{38}$ važan je za naš pregled teoze jer „pretpostavlja shvaćanje da se pala ljudska narav može očistiti po vjeri u Isusa Krista i po sili Svetog Duha. U takvom stanju, vjerniku je dana duhovna snaga i može održavati čistoću srca“ (Collins 2012, 163).

\section{Zaključak u vezi povijesti doktrine o teozi}

Doktrina teoze konstruirana je tijekom razdoblja patrističke teologije. Svoj razvoj započela je s ranim očevima, a izričito je oblikovana od strane određenih kasnih otaca. Doktrina je bila prisutna u različitim mjerama u raznim kršćanskim centrima po čitavom kršćanskom svijetu u vrijeme Rimskog Carstva. U srednjem i kasnom srednjovjekovnom razdoblju, istočni teolozi prihvatili su teozu kao glavnu nauku. Tako je ona postala glavnom doktrinom spasenja, uključujući svrhu čovječanstva i čitavog kozmosa. Teoza nije postala glavnom doktrinom na $\mathrm{Za}$ padu, ali koncept je teoze uvijek bio prisutan, čak i kod glavnih teologa različitih

35 Kršćansko savršenstvo je „gledište da je ljudsko savršenstvo moguće tako što kršćanski vjernici više ne griješe" (McKim 1996, 207). Naglasak je na jedinstvu s Bogom, zrelosti i savršenstvu u ljubavi prema Bogu i ljudima.

36 Potpuno posvećenje ,je gledište koje nalazimo u wesleyanskim tradicijama i tradicijama svetosti koja naučavaju da kršćanin može postići slobodu od grijeha i potpuno posvećenje ili svetost u ovom životu“ (McKim 1996, 90). Naglasak je na jedinstvu s Bogom, zrelosti i savršenstvu u ljubavi prema Bogu i ljudima.

37 Oksfordski pokret bio je „pokret u 19. stoljeću za obnovu crkve unutar Engleske crkve i unutar Anglikanizma... koji je nastojao obnoviti 'katoličke' elemente u crkvenoj doktrini i pobožnosti“ (McKim 1996, 198).

38 Pokret svetosti odnosi se na „američke vjerske zajednice u devetnaestom stoljeću koje su nastojale promicati metodistička gledišta potpunog posvećenja i koncept kršćanske savršenosti kako ga je shvaćao John Wesley“ (McKim 1996, 130). 
zapadnih tradicija. S obzirom na kršćanske mislioce koje sam prikazao, teoza se može smatrati jednom od ključnih povijesnih doktrina Crkve.

\section{Literatura}

Ackerman, James S. 1966. "The Rabbinic Interpretation of Psalm 82 and the Gospel of John.” Harvard Theological Review 59, no. 2 (April): 186191. Pristupljeno 22. svibnja 2017. ATLA Religion Database with ATLASerials, EBSCOhost.

Athanasius. n.d. On the Incarnation of the Word. Grand Rapids: Christian Classics Ethereal Library. Pristupljeno 3. srpnja 2017. http://www.ccel.org/ ccel/athanasius/incarnation.pdf.

Augustine, Saint. 1992. Sermons on the New Testament (vol. III/5). In The Works of Saint Augustine: A Translation for the 21st Century. Hyde Park: New City Press.

Augustine, St. Aurelius. 2007. Expositions on the Psalms. Digital version. Compiled by Ted Hildebrandt. Pristupljeno 2. srpnja 2017. https://faculty.gordon. edu/hu/bi/ted_hildebrandt/otesources/19-psalms/text/ books/augustinepsalms/augustine-psalms.pdf.

Barclay, William. 1960. The Letters of James and Peter. Philadelphia: Westminster Press.

Bigg, Charles. 1956. A Critical and Exegetical Commentary on the Epistles of St. Peter and St. Jude. Edinburgh: T \& T Clark.

Braaten, Carl E., and Robert W. Jenson. 1998. "The Finnish Breakthrough in Luther Research." In Union with Christ. Grand Rapids: Eerdmans. Kindle.

Brant, Jo-Ann A. 2011. John. Grand Rapids: Baker Academic.

Brown, Raymond E. 2008. The Gospel According to John (I-XII). The Anchor Yale Bible. New Haven and London: Yale University Press.

Cheng, John. n.d. "The Distinction between God's Essence and Energy: Gregory Palamas' Idea of Ultimate Reality and Meaning." 91-117. Pristupljeno 17. srpnja 2017. http://catholic-church.org/grace/ecu/v/4.pdf.

Clendenin, Daniel B. 1994. "Partakers of Divinity: The Orthodox Doctrine of Theosis." Journal of the Evangelical Theological Society 37, no. 3 (September): 365-379. Pristupljeno 13. studenog 2017. ATLA Religion Database with ATLASerials, EBSCOhost.

Closson, David. 2016. "What Does It Mean to Be Made in God's Image?" Ethics and Religious Liberty Commission (May 4). Pristupljeno 10. svibnja 2017. 
http://erlc.com/resource-library/articles/what-does-it-mean-to-be-madein-gods-image.

Collins, Paul M. 2012. Partaking in Divine Nature: Deification and Communion. London: Bloomsbury T \& T Clark.

Corbin-Reuschling, Wyndy. 2014. "The Means and End in 2 Peter 1:3-11: The Theological and Moral Significance of Theōsis." Journal of Theological Interpretation 8, no. 2 (September): 275-286. Pristupljeno 26. svibnja 2017. ATLA Religion Database with ATLASerials, EBSCOhost.

Dionysius the Areopagite. 1897. Ecclesiastical Hierarchy. In Dionysius the Areopagite, Works (1897). Grand Rapids: Christian Classics Ethereal Library. Pristupljeno 10. srpnja 2017. http://www.ccel.org/ccel/Dionysius /works. pdf.

Finch, Jeffrey. 2006a. "Athanasius on the Deifying Work of the Redeemer." In Theōsis: Deification in Christian Theology, 104-121. Eugene: Pickwick Publications.

Finch, Jeffrey. 2006b. "Irenaeus on the Christological Basis of Human Divinization." In Theōsis: Deification in Christian Theology, 86-103. Eugene: Pickwick Publications.

Finlan, Stephen, and Vladimir Kharlamov, eds. 2006. Theossis: Deification in Christian Theology. Princeton Theological Monograph Series. Eugene: Pickwick Publications.

Fretheim, Terence E. 1994. “Genesis 1:1-11:26, The Primeval Story." In The Book of Genesis, The New Interpreter's Bible, vol. I. Nashville: Abingdon Press. Pristupljeno 15. svibnja 2017. http://www.ministrymatters.com.vwproxy. lipscomb.edu/library/\#/tnib/df3e531e83bd95992b9aa6486a7f6508/genesis11-1126.html.

Fretheim, Terence E. 2008. "Image of God." In The New Interpreter's Dictionary of the Bible. Nashville: Abingdon Press. Pristupljeno 10. svibnja 2017. http://www.ministrymatters.com.vwproxy.lipscomb.edu/library/\#/nidb/12 016f6d65c14a542e811a8194fb4357/image-of-god.html.

Gorman, Michael J. 2009. Inhabiting the Cruciform God: Kenosis, Justification, and Theosis in Paul's Narrative Soteriology. Grand Rapids: Eerdmans. Kindle.

Gorman, Michael J. 2011. "Romans: The First Christian Treatise on Theosis." Journal of Theological Interpretation 5, no. 1: 13-34. Pristupljeno 21. rujna 2017. ATLA Religion Database with ATLASerials, EBSCOhost.

Green, Michael. 1989. The Second Epistle General of Peter, and the General Epistle of Jude. Rev. ed. Grand Rapids: Eerdmans. 
Hafemann, Scott J. 2013. "'Divine Nature' in 2 Pet 1,4 within its Eschatological Content." Biblica 94, no. 1: 80-99. Pristupljeno 26. svibnja 2017. ATLA Religion Database with ATLASerials, EBSCOhost.

Hartley, John E. 2008. Genesis. New International Biblical Commentary 1. Peabody: Hendrickson Publishers.

Irenaeus, Saint. n.d. Against Heresies. New Advent: Online Content. Pristupljeno 3. srpnja 2017. https://archive.org/details/ SaintIrenaeusAgainstHeresiesComplete.

Kharlamov, Vladimir. 2006a. "Deification in the Apologists of the Second Century." In Theosis: Deification in Christian Theology, 67-85. Eugene: Pickwick Publications.

Kharlamov, Vladimir. 2006b. "Emergence of the Deification Theme in the Apostolic Fathers." In Theōsis: Deification in Christian Theology, 51-66. Eugene: Pickwick Publications.

Kirkpatrick, A. F. 1906. “Psalm 82.” In Psalms, The Cambridge Bible for Schools and Colleges. Cambridge: Cambridge University Press. Pristupljeno 18. svibnja 2017. http://biblehub.com/commentaries/cambridge/psalms/82. htm.

Kysar, Robert. 1986. John. Augsburg Commentary on the New Testament. Minneapolis: Augsburg Publishing House.

Lenker, John Nicholas, ed. n.d. Sermons by Martin Luther, vol. 8. Pristupljeno 20. srpnja 2017. http://www.martinluthersermons. com/Luther_Lenker_ Vol_8.pdf.

Lenz, John R. 2008. "Deification of the Philosopher in Classical Greece." In Partakers of the Divine Nature, 47-67. Grand Rapids: Baker Academic.

Leupold, H. C. 1974. Exposition of the Psalms. Grand Rapids: Baker Book House.

Litwa, M. David. 2012. We Are Being Transformed: Deification in Paul's Soterio$\log y$. Berlin: De Gruyter.

Lossky, Vladimir. 2002. The Mystical Theology of the Eastern Church. Crestwood, NY: St. Vladimir's Seminary Press.

Mannermaa, Tuomo. 1998. "Justification and Theosis in Lutheran-Orthodox Perspective." In Union with Christ. Grand Rapids: Eerdmans. Kindle.

Maximus, Saint. 2015. The Writings of Saint Maximus the Confessor. Philadelphia: R.P. Pryne. Kindle.

MacLaren, Alexander. n.d. "2 Peter i.4 - Partakers of the Divine Nature." In Expositions of Holy Scripture, vol. 17, 25-32. Pristupljeno 26. svibnja 2017. 
http://www.graceebooks.com/library/Alexander\%20Maclaren/ 17\%20\%20 Expositions\%20of\%20Holy\%20Scripture.pdf.

Meconi, David Vincent. 2013. The One Christ: St. Augustine's Theology of Deification. Washington: Catholic University of America Press.

McCann, J. Clinton Jr. 1996. "Psalms 82:1-8, Show Justice to the Weak." In The Book of Psalms, The New Interpreter's Bible, vol. IV. Nashville: Abingdon Press. Pristupljeno 18. svibnja 2017. http://www .ministrymatters.com.vwproxy.lipscomb.edu/library/\#/tnib/d2e753edde57c9df82e385297df0bc13/psalms-821-8-show-justice-to-the-weak.html.

McCullough, W. Stewart. 1980. "LXXXII. A Scene in Heaven (82:1-8).” In The Book of Psalms, The Interpreter's Bible. Nashville: Abingdon Press. Pristupljeno 18. svibnja 2017. http://www.ministrymatters .com.vwproxy. lipscomb.edu/library/\#/ibnew/cd33e0cc02e48ee2fcac332cef172428/lxxxiia-scene-in-heaven-821-8.html.

McGinn, Bernard. 2006. The Essential Writings of Christian Mysticism. New York: Modern Library.

McGuckin, J. A. 2008. "The Strategic Adaptation of Deification in the Cappadocians." In Partakers of the Divine Nature, 95-114. Grand Rapids: Baker Academic.

McKim, Donald K. 1996. Westminster Dictionary of Theological Terms. Louisville: Westminster John Knox Press.

Morris, Henry M. The Genesis Record. Grand Rapids: Baker Book House, 1976.

Mosser, Carl. 2005. "The Earliest Patristic Interpretations of Psalm 82, Jewish Antecedents, and the Origin of Christian Deification." The Journal of Theological Studies 56, no. 1 (April): 30-74. Pristupljeno 18. svibnja 2017. ATLA Religion Database with ATLASerials, EBSCOhost.

Mounce, William D. 2003. Basics of Biblical Greek Grammar. 2nd ed. Grand Rapids: Zondervan.

Nispel, Mark. 1999. "Christian Deification and the Early Testimonia." Vigiliae Christianae 53, no. 3 (January 1): 289-304.

O’Day, Gail R. 1995. “John 10:22-42, Jesus at the Feast of Dedication.” In The Gospel of John, The New Interpreter's Bible, vol. IX. Nashville: Abingdon Press. Pristupljeno 22. svibnja 2017. http://www.ministrymatters.com. vwproxy.lipscomb.edu/library/\#/tnib/492e34a93b440c6734e13eb2593746f 9/john-1022-42-jesus-at-the-feast-of-dedication.html.

Olson, Roger E. 2007. "Deification in Contemporary Theology." Theology Today 64, no. 2 (July 1,): 186-200. 
Origen. n.d. Contra Celsus. Pristupljeno 10. srpnja 2017. http://www.documenta-catholica.eu/d_0185-0254-\%20Origene\%20-\%20 Contra\%20Celsus\%20 -\%20EN.pdf.

Phillips, W. Gary. 1989. “An Apologetic Study of John 10:34-36.” Bibliotheca Sacra 146, no. 584 (October): 405-419. Pristupljeno 22. svibnja 2017. ATLA Religion Database with ATLASerials, EBSCOhost.

Plummer Alfred. 1902. "John 10." In John, The Cambridge Bible for Schools and Colleges. Cambridge: Cambridge University Press. Pristupljeno 22. svibnja 2017. http://biblehub.com/commentaries/cambridge/john/10.htm.

Puchniak, Robert. 2006. “Augustine's Conception of Deification, Revisited.” In Theōsis: Deification in Christian Theology, 122-133. Eugene: Pickwick Publications.

Rakestraw, Robert V. 1997. "Becoming Like God: An Evangelical Doctrine of Theosis." Journal of the Evangelical Theological Society 40, no. 2 (June 1): 257-269.

Reicke, Bo. 1964. The Epistles of James, Peter and Jude. The Anchor Bible. Garden City: Doubleday.

Russell, Norman. 2004. The Doctrine of Deification in the Greek Patristic Tradition. Oxford: Oxford University Press. Kindle.

Spurgeon, C. H. 1988. The Treasury of David. Peabody: Hendrickson Publishers.

Strobel, Kyle. 2012. "Jonathan Edwards and the Polemics of Theosis." Harvard Theological Review 105:3: 259-279.

Turner, David L. 1996. “Image of God.” In Baker's Evangelical Dictionary of Biblical Theology. Grand Rapids: Baker Books. Pristupljeno 15. svibnja 2017. http://www.biblestudytools.com/dictionaries/bakers-evangelical-dictionary/image-of-god.html.

Vishnevskaya, Elena. 2006. "Divinization and Spiritual Progress in Maximus the Confessor." In Theōsis: Deification in Christian Theology, 134-145. Eugene: Pickwick Publications.

Watson, Duane F. 1998. “2 Peter 1:3-11.” In The Second Letter of Peter, The New Interpreter's Bible, vol. XII. Nashville: Abingdon Press. Pristupljeno 26. svibnja 2017. http://www.ministrymatters.com.vwproxy.lipscomb.edu/library/\#/tnib/05d4c7ca74b1813clab505369084a11e/2-peter-13-11.html.

Wilcock, Michael. 2001. The Message of Psalms 73-150. Downers Grove: InterVarsity Press.

Williams, A. N. 1999. The Ground of Union: Deification in Aquinas and Palamas. New York: Oxford University Press. Kindle. 
Wolters, Albert M. 1990. 'Partners of the Deity': A Covenantal Reading of 2 Peter 1:4." Calvin Theological Journal 25, no. 1 (April): 28-44. Pristupljeno 26. svibnja 2017. ATLA Religion Database with ATLASerials, EBSCOhost.

\author{
Goran Medved
}

\title{
Theosis (Deification) as a Biblical and Historical Doctrine
}

\begin{abstract}
Summary
This is the first of the two articles by this author that research the doctrine of theosis, sometimes also called deification or divinization. The second article presents theosis as a New Testament and evangelical doctrine. This first article presents theosis as a biblical and historical doctrine. The first major section of this article analyzes the main biblical texts for the doctrine of theosis; their interpretation and appropriation for theosis. The second major section of this article gives an overview of historical development of the doctrine of theosis, from the beginning of Christian thought to modern era. It shows that theosis was not limited to Eastern theologians but was also represented in the West in certain mainstream theologians and movements. Because of its biblicity and historicity, theosis should be considered an essential historical doctrine of the Church.
\end{abstract}

